OPEN ACCESS

Indonesian Journal of Human Nutrition
P-ISS 2424-6636
E-ISS 2355-3987
www.jignn.ub.acid

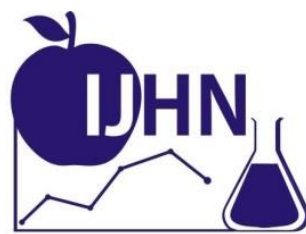

Artikel Hasil Penelitian

\title{
Formulasi Food Bar Tepung Bekatul dan Tepung Jagung sebagai Pangan Darurat
}

(Formulation of Rice Bran Fluor and Corn Fluor as Emergency Food Product)

\author{
Inggita Kusumastuty ${ }^{1}$, Laily Fandianty Ningsih ${ }^{1}$, Arliek Rio Julia ${ }^{2}$ \\ ${ }^{1}$ Program Studi Ilmu Gizi Fakultas Kedokteran Universitas Brawijaya \\ ${ }^{2}$ Laboratorium Anatomi Fakultas Kedokteran Universitas Brawijaya \\ *Alamat korespondensi, E-Mail: inggita.kusuma@gmail.com
}

Diterima: / Direview: / Dimuat: Juli 2014 / Oktober 2014 / Desember 2015

\begin{abstract}
Abstrak
Pangan darurat merupakan pangan yang dalam keadaan darurat diharapkan dapat memenuhi kebutuhan sebesar 233-250 kkal/50 gram bahan. Salah satu contoh produk pangan darurat adalah food bar. Bahan baku yang digunakan dalam pembuatan food bar ini berasal dari tepung bekatul dan tepung jagung. Bekatul dan jagung dipilih karena selama ini pemanfaatan bekatul masih terbatas untuk pangan, padahal kandungan gizinya dapat dimanfaatkan dalam mengembangkan suatu produk food bar. Sementara itu jagung dipilih karena jagung merupakan penyumbang terbesar kedua setelah padi dalam subsektor tanaman pangan. Tujuan penelitian ini adalah untuk mengetahui formulasi food bar dari tepung bekatul dan tepung jagung yang sesuai syarat pangan darurat dan daya terima produk. Penelitian ini menggunakan desain true experiment dengan Rancangan Acak Lengkap (RAL). Perbandingan tepung bekatul dan tepung jagung yang diterapkan adalah 10:90, 20:80, 30:70, 40:60, 50:50. Uji yang dilakukan adalah uji Kruskall Wallis dan uji Man Whitney dengan taraf kepercayaan 95\%. Hasil penelitian menunjukkan bahwa formulasi food bar berbahan baku tepung bekatul dan tepung jagung tidak berbeda terhadap parameter mutu gizi protein $(\mathrm{p}=0,187)$, lemak $(\mathrm{p}=0,852)$, karbohidrat $(\mathrm{p}=0,114)$, akan tetapi memberikan perbedaan yang signifikan terhadap parameter mutu organoleptik rasa $(\mathrm{p}=0,004)$, aroma $(\mathrm{p}=0,016)$, tekstur $(\mathrm{p}=0,005)$, warna $(\mathrm{p}=0,004)$. Maka food bar yang tepat sesuai syarat pangan darurat dan baik daya terimanya adalah food bar dengan tepung bekatul : tepung jagung (10:90) yang mengandung energi 232,43 kkal, protein 6,35 gram, lemak 9,41 gram dan karbohidrat 30,58 gram dalam 50 gram bahan serta memiliki tingkat kesukaan "suka" pada rasa, aroma dan tekstur, dan tingkat kesukaan "sangat suka" pada warna.

Kata kunci: pangan darurat, food bar, bekatul, jagung, mutu gizi.
\end{abstract}

\section{Abstract}

Emergency food products are food in emergency situation that are expected to meet requirements of 233-250 kcal/50 grams food. One of the forms of emergency food product is food bar. Materials used in this research were rice bran flour and corn flour. This study aims to determine the food bar formulation of rice bran flour and corn flour that is appropriate with 
emergency food product requirements and product acceptance. True experiment with a completely randomized design (CRD) were used in this study. The independent variables were amount of wheat flour (100\%) and amount of rice bran flour: corn flour (10:90, 20:80, 30:70, 40:60, 50:50), while the dependent variable was the value of macronutrients (protein, fat, carbohydrate) and physical quality (texture, flavor, color, scent). Statistical test used kruskall Wallis and Mann-Whitney with level of credibility 95\%. The results showed that the formulation of food bar from rice bran flour and corn flour did not have any difference with nutritional quality parameters of protein $(\mathrm{p}=0,187)$, fat $(\mathrm{p}=0,852)$, carbohydrate $(\mathrm{p}=0,114)$, but had a significant difference with organoleptic quality of taste $(\mathrm{p}=0,004)$, aroma $(\mathrm{p}=0,016)$, texture $(\mathrm{p}=0,005)$, color $(\mathrm{p}=0,004)$. In conclusion, the food bar that was suited with food product requirements and product acceptance was food bar with rice bran flour:corn flour (10:90) containing energy $232,43 \mathrm{kcal}$, 6,35 protein grams, 9,41 fat grams and carbohydrate 30,58 grams in 50 grams of food bar and had preference level "likes" on flavor, scent and texture, and "really like" on color.

Keyword : Emergency food product, food bar, rice bran, corn, nutritional quality

\section{PENDAHULUAN}

Indonesia merupakan negara yang rawan bencana. Indonesia menempati urutan ketiga di dunia sebagai negara rawan bencana setelah India dan China [1]. Dalam kondisi serba darurat, salah satu bantuan yang sangat dibutuhkan korban bencana adalah makanan. Pada keadaan seperti ini, diperlukan desain pangan khusus untuk keadaan darurat bencana yang dapat langsung dikonsumsi (ready to eat), praktis untuk didistribusikan, dan bergizi. Salah satu alternatif pangan yang dapat diberikan pada para pengungsi adalah pangan darurat [2].

Pangan darurat atau Emergency Food Product (EFP) adalah makanan yang memiliki energi dan densitas zat gizi yang tinggi untuk korban bencana alam yang dapat dikonsumsi segera pada keadaan darurat. Penggunaan pangan darurat dapat dilakukan selama 3 sampai 7 hari dan maksimal 15 hari. Produk ini bisa digunakan pada daerah yang memiliki iklim ekstrim dari kutub utara sampai tropis [3].

Produk pangan darurat harus dapat dikonsumsi secara langsung dan cocok untuk segala usia mulai dari anak berusia 6 bulan sampai orang tua. Terdapat lima karakter dari pangan darurat, yaitu aman, rasa dapat diterima, mudah dibagikan, mudah digunakan, zat gizi lengkap [3]. Produk pangan darurat sebaiknya berbentuk segi empat untuk efisiensi saat proses pembungkusan. Warna dari food bar tergantung dari bahan yang digunakan dan proses produksi yang digunakan.

Tabel 1. Syarat Kandungan Zat Gizi Pangan Darurat

\begin{tabular}{ccc}
\hline Zat Gizi & $\begin{array}{c}\text { Kebutuhan Minimal } \\
\text { / 50 gr EFP* }\end{array}$ & $\begin{array}{c}\text { Kebutuhan Maksimal } \\
\text { /50 gr EFP* }\end{array}$ \\
\hline Energi & $233 \mathrm{kkal}$ & $250 \mathrm{kkal}$ \\
Lemak & 9,1 gram & 11,7 gram \\
& (35\% dari kalori) & $(45 \%$ dari kalori) \\
Protein & 7,9 gram & 8,9 gram \\
Total Karbohidrat & $(10 \%$ dari kalori) & $(15 \%$ dari kalori) \\
Total Gula & 11,7 gram & 14,7 gram \\
& (40\% dari kalori) & $(50 \%$ dari kalori) \\
\hline
\end{tabular}

(Zoumas et al., 2002)

Ket: *EFP = Emergency Food Product (Produk Pangan Darurat)

Produk pangan darurat harus memenuhi kebutuhan 2100 kkal dan dapat dibagi dalam sembilan bar dimana setiap bar sama dengan dua porsi dan setiap porsi menghasilkan $116 \mathrm{kkal}$. Total 
berat keseluruhan (2100 kkal) kira-kira 450 gram (50gram/bar). Kebutuhan energi 233-250 kkal didapat dari makronutrien yaitu protein sebesar 10$15 \%$, lemak sebesar $35-45 \%$ dan karbohidrat sebesar $40-50 \%$ [3].

Salah satu contoh produk pangan darurat yang memiliki umur simpan yang cukup lama adalah food bar. Food bar merupakan salah satu produk pangan olahan kering berbentuk batang yang memiliki nilai aw (water activity) rendah yang dapat menghambat pertumbuhan mikroba sehingga memiliki umur simpan yang cukup panjang. Food bar memiliki bentuk batang yang memudahkan dalam pengemasan dan penghematan tempat sehingga proses pendistribusian menjadi lebih efisien [4]. Bahan baku yang digunakan dalam pembuatan food bar dapat berasal dari tepung bekatul dan tepung jagung.

Departemen Pertanian (2002) menyebutkan bahwa ketersediaan bekatul di indonesia cukup banyak mencapai 4,5-5 juta ton setiap tahunnya [5]. Bekatul merupakan hasil samping proses penggilingan beras pecah kulit yang terdiri dari lapisan dalam pembungkus pecah kulit, sebagian lembaga serta endosperm dalam jumlah sedikit [6]. Pemanfaatan bekatul masih terbatas sebagai pakan yang nilai ekonomisnya rendah namun sebenarnya bekatul dapat dimanfaatkan sebagai bahan pangan. Hal ini disebabkan bekatul memiliki nilai gizi yang cukup tinggi yaitu $11,8-13 \%$ protein, $10,1-13,4 \%$ lemak, 2,3-3,2\% serat, dan 51,1-55\% karbohidrat. Selain itu bekatul juga kaya akan vitamin dan mineral seperti kalsium, magnesium, fosfor, seng, thiamin, riboflavin, dan niasin [6].

Dalam perekonomian nasional, jagung adalah penyumbang terbesar kedua setelah padi dalam subsektor tanaman pangan [7]. Pemilihan jagung sebagai bahan baku alternatif dalam pembuatan food bar sejalan dengan program pemerintah dalam upaya diversifikasi pangan. Menurut data Badan Pusat Statistik (2007) menyatakan bahwa produksi jagung nasional pada tahun 2006 mencapai 11,6 juta ton [8].

Tepung jagung merupakan butiran - butiran halus yang berasal dari jagung kering yang digiling. Tepung jagung dapat digunakan sebagai alternatif tepung terigu untuk membuat beraneka ragam makanan. Di samping itu, tepung jagung memiliki kelebihan lebih tahan disimpan, mudah dicampur denga bahan lain, dapat diperkaya zat gizi, lebih praktis, dan mudah digunakan untuk proses pengolahan lanjutan [9]. Memperhatikan uraian diatas, peneliti ingin mengetahui mutu organoleptik dan nilai gizi formulasi food bar tepung bekatul dan tepung jagung sebagai pangan darurat dengan berbagai kombinasi formula yang berbeda.

\section{METODE PENELITIAN}

Penelitian ini dilaksanakan setelah mendapatkan Surat Keterangan Kelaikan Etik dari Komisi Etik Penelitian Kesehatan Fakultas Kedokteran Universitas Brawijaya dengan Nomor 436/KEPK-S1-GZ/EC/09/2013. Jenis penelitian adalah penelitian true experiment dengan desain penelitian Rancangan Acak Lengkap (RAL). Penelitian ini dilakukan dengan 4 taraf perlakuan dan 1 kelompok kontrol seperti di bawah ini:

P0 : tepung gandum $100 \%$

PI : tepung bekatul $10 \%$ dan tepung jagung $90 \%$ P2: tepung bekatul $20 \%$ dan tepung jagung $80 \%$ P3: tepung bekatul $30 \%$ dan tepung jagung $70 \%$ P4: tepung bekatul $40 \%$ dan tepung jagung $60 \%$ P5: tepung bekatul $50 \%$ dan tepung jagung $50 \%$ Jumlah sampel keseluruhan adalah 24 sampel.

Pada penelitian ini parameter yang diukur adalah mutu gizi (kadar protein diukur dengan metode Kjehdahl, kadar lemak diukur dengan metode Soxhlet, kadar karbohidrat dengan metode by difference (metode tidak langsung)), dan mutu organoleptik dengan metode hedonik. Analisis statistik yang dilakukan adalah uji Kruskall Wallis dan uji Man Whitney dengan taraf kepercayaan $95 \%$.

\section{HASIL PENELITIAN}

Penentuan proporsi tepung dan bahan lain diperoleh dari hasil penelitian Brisske (2004) dalam Ricelina (2007) dan hasil penelitian pendahuluan [10]. Food bar yang dihasilkan memiliki ukuran panjang $9 \mathrm{~cm}$; lebar $6 \mathrm{~cm}$ dan tebal $0,7 \mathrm{~cm}$ dengan berat 50 gram setiap batang. 
Tabel 2. Formula Food Bar

\begin{tabular}{cc}
\hline Nama Bahan & Jumlah \\
\hline Tepung & $50 \%$ \\
Margarin & $10 \%$ \\
Madu & $22 \%$ \\
Kacang Tanah & $18 \%$ \\
\hline
\end{tabular}

Seluruh perlakuan food bar dianalisis zat gizinya. Zat gizi yang dianalisis dari sampel adalah protein, lemak dan karbohidrat. Analisis kadar protein food bar dianalisis menggunakan metode Kjeldahl, analisis kadar lemak menggunakan metode Soxhlet. Sedangkan analisis kadar karbohidrat menggunakan metode by difference (metode tidak langsung).
Dari analisa mutu gizi yang didapatkan dapat diketahui energi yang terkandung dalam 50 gram food bar dengan cara menghitung secara tidak langsung. Energi merupakan jumlah energi yang tersimpan dalam makanan yang telah ditentukan per unit volume atau massa, lemak menyimpan 9 kkal/gram, karbohidrat dan protein masing masing menyimpan 4 kkal/gram [11].

Tabel 3. Persentase Energi dan Zat gizi Food Bar per 50 gram

\begin{tabular}{ccccc}
\hline Perlakuan & \multicolumn{3}{c}{ Mutu Zat Gizi } & Energi (kkal) \\
\cline { 2 - 4 } P0 & Protein (\%) & Lemak (\%) & Karbohidrat (\%) & 229,79 \\
P1 & 12,12 & 18,62 & 60,86 & 232,43 \\
P2 & 12,71 & 18,82 & 61,16 & 231,68 \\
P3 & 10,58 & 18,69 & 63,19 & 231,34 \\
P4 & 10,74 & 18,74 & 62,76 & 230,81 \\
P5 & 12,38 & 18,34 & 61,76 & 229,20 \\
\hline
\end{tabular}

Kadar protein tertinggi yaitu pada sampel perlakuan P1. Sampel perlakuan P1 merupakan Food bar dengan proporsi $10 \%$ tepung bekatul dan $90 \%$ tepung jagung. Kadar protein sampel perlakuan P1 12,71 gram, lebih besar dari pada P0 (kontrol 100\% tepung gandum). Kadar protein sampel P2, P3 dan P5 lebih rendah dari P0. Sedangkan P4 lebih tinggi dari P0. Secara keseluruhan menurut syarat pangan darurat, semua perlakuan telah memenuhi syarat tersebut. Yaitu kandungan protein sebesar $10-15 \%$.

Berdasarkan hasil uji statistik Kruskal Wallis pada tingkat kepercayaan 95\% $(\mathrm{p}<0,05)$ menunjukkan bahwa formulasi food bar berbahan baku tepung bekatul dan tepung jagung tidak berbeda $(\mathrm{p}=0,187)$ terhadap parameter mutu gizi protein.

Kadar lemak tertinggi yaitu pada sampel perlakuan P1. Sampel perlakuan P1 merupakan Food bar dengan proporsi $10 \%$ tepung bekatul dan $90 \%$ tepung jagung. Kadar protein sampel perlakuan P1 18,82 gram, lebih besar dari pada P0 (kontrol 100\% tepung gandum). Kadar lemak sampel P4 dan P5 lebih rendah dari P0. Sedangkan P2 dan P3 lebih tinggi dari P0. Secara keseluruhan menurut syarat pangan darurat, semua perlakuan tidak memenuhi syarat tersebut yaitu kandungan lemak sebesar $35-45 \%$.

Berdasarkan hasil uji statistik Kruskal Wallis pada tingkat kepercayaan 95\% $(\mathrm{p}<0,05)$ menunjukkan bahwa formulasi food bar berbahan baku tepung bekatul dan tepung jagung tidak berbeda $(\mathrm{p}=0,852)$ terhadap parameter mutu gizi lemak.

Kadar karbohidrat tertinggi yaitu pada sampel perlakuan P2. Sampel perlakuan P2 merupakan Food bar dengan proporsi 20\% tepung bekatul dan $80 \%$ tepung jagung. Kadar karbohidrat sampel perlakuan P2 63.1925 gram, lebih besar dari pada P0 (kontrol 100\% tepung gandum). Kadar karbohidrat sampel P2, P3, P4 dan P5 lebih tinggi dari P0. Secara keseluruhan menurut syarat pangan darurat, semua perlakuan tidak memenuhi syarat tersebut yaitu kandungan karbohidrat sebesar 40 $50 \%$.

Berdasarkan hasil uji statistik Kruskal Wallis pada tingkat kepercayaan 95\% $(\mathrm{p}<0,05)$ menunjukkan bahwa formulasi food bar berbahan baku tepung bekatul dan tepung jagung tidak berbeda $(p=0,114)$ terhadap parameter mutu gizi karbohidrat. 
Berdasarkan jumlah energi pada setiap food bar, dapat diketahui semua perlakuan tidak memenuhi syarat minimal pangan darurat yaitu 233 kkal. Akan tetapi, total energi yang paling mendekati syarat energi pangan darurat adalah $\mathrm{P} 1$ (tepung bekatul 10\%: tepung jagung 90\%).

Tabel 4. Mutu Organoleptik

\begin{tabular}{|c|c|c|c|c|c|}
\hline \multicolumn{2}{|c|}{ Perlakuan } & \multicolumn{4}{|c|}{ Mutu Organoleptik } \\
\hline & & Rasa & Aroma & Tekstur & Warna \\
\hline \multirow[t]{2}{*}{ P0 } & TK & 3 & 3 & 2 & 4 \\
\hline & Mo & 10 & 9 & 9 & 9 \\
\hline \multirow[t]{2}{*}{ P1 } & TK & 4 & 4 & 4 & 5 \\
\hline & Mo & 14 & 12 & 18 & 9 \\
\hline \multirow[t]{2}{*}{ P2 } & TK & 4 & 3 & 3 & 4 \\
\hline & Mo & 10 & 13 & 9 & 14 \\
\hline \multirow[t]{2}{*}{ P3 } & TK & 4 & 4 & 4 & 4 \\
\hline & Mo & 10 & 13 & 9 & 13 \\
\hline \multirow[t]{2}{*}{ P4 } & TK & 2 & 4 & 4 & 3 \\
\hline & Mo & 10 & 10 & 11 & 13 \\
\hline \multirow[t]{2}{*}{ P5 } & TK & 3 & 3 & 2 & 2 \\
\hline & Mo & 10 & 10 & 9 & 10 \\
\hline \multicolumn{2}{|c|}{ p-value } & 0,004 & 0,016 & 0,005 & 0,004 \\
\hline
\end{tabular}

Keterangan :

- TK (Tingkat kesukaan) 5,4,3,2,1 = sangat suka, suka, biasa, tidak suka, sangat tidak suka.

- Mo = Nilai Modus

Modus Penilaian panelis terhadap rasa menunjukkan bahwa sampel P0 dan P5 memiliki modus penilaian "biasa" dengan masing-masing 10 . Sampel P1 dan P2 memiliki modus penilian "suka" dengan masing-masing 14 dan 10. P3 memiliki 2 modus penilaian yaitu "biasa" dan "suka". Nilai modus P3 yaitu 10 untuk masing-masing penilaian yaitu "biasa" dan "suka", sedangkan sampel P4 memiliki modus penilaian "tidak suka" pada nilai 10.

Berdasarkan hasil uji statistik Kruskal Wallis pada tingkat kepercayaan 95\% $(\mathrm{p}<0,05)$ menunjukkan bahwa formulasi food bar berbahan baku tepung bekatul dan tepung jagung memberikan perbedaan yang signifikan $(p=0,004)$ terhadap parameter mutu organoleptik rasa.

Modus penilaian panelis terhadap aroma menunjukkan bahwa sampel P0, P2, dan P3 memiliki modus penilian "biasa" dengan masingmasing 9, 12 dan 10. Sampel P1 dan P3 memiliki modus penilaian "suka" dengan masing-masing 12 dan 13. P4 memiliki 2 modus penilaian yaitu "biasa" dan "suka". Nilai modus P4 yaitu 10 untuk masing-masing penilaian yaitu "biasa" dan "suka".

Berdasarkan hasil uji statistik Kruskal Wallis pada tingkat kepercayaan 95\% (p<0,05) menunjukkan bahwa formulasi food bar berbahan baku tepung bekatul dan tepung jagung memberi- kan perbedaan yang signifikan $(\mathrm{p}=0,016)$ terhadap parameter mutu organoleptik aroma.

Modus penilaian panelis tekstur menunjukkan bahwa sampel P0 dan P5 memiliki modus penilaian "tidak suka" dengan masing-masing 9 dan 9. Sampel P1, P3 dan P4 memiliki modus penilaian "suka" dengan masing-masing 8, 9 dan 11, sedangkan sampel P2 memiliki modus penilaian "biasa" pada nilai 9.

Hasil uji statistik Kruskal Wallis pada tingkat kepercayaan 95\% ( $\mathrm{p}<0,05)$ menunjukkan bahwa formulasi food bar berbahan baku tepung bekatul dan tepung jagung memberikan perbedaan yang signifikan $(p=0,005)$ terhadap parameter mutu organoleptik tekstur.

Modus penilaian panelis terhadap warna menunjukkan bahwa sampel P0, P2, dan P3 memiliki modus penilaian "suka" dengan masingmasing 9, 14, dan 13. Sampel P1 memiliki modus penilaian "sangat suka" dengan nilai 9. Sampel P4 memiliki modus penilaian "biasa" pada nilai 13, sedangkan sampel P5 memiliki modus penilaian "tidak suka" pada nilai 10 .

Berdasarkan hasil uji statistik Kruskal Wallis pada tingkat kepercayaan 95\% $(\mathrm{p}<0,05)$ menunjukkan bahwa formulasi food bar berbahan baku tepung bekatul dan tepung jagung memberikan perbedaan yang signifikan $(p=0,004)$ terhadap parameter mutu organoleptik warna. 


\section{PEMBAHASAN}

Pada penelitian ini dilakukan pengukuran kandungan Energi dan zat gizi makro (protein, lemak dan karbohidrat) pada produk food bar yang dihasilkan pada seluruh taraf perlakukan. Uji proksimat pada bahan yang digunakan yaitu tepung bekatul dan tepung jagung tidak dilakukan. Hasil menunjukkan bahwa seluruh food bar yang dihasilkan tidak memenuhi syarat minimal dari pangan darurat untuk lemak, karbohidrat dan energi. Akan tetapi memenuhi syarat pangan darurat untuk protein.

Pada produk food bar ini kandungan proteinnya berkisar $10-12 \%$. Perbedaan antara P1 sampai P5 tidaklah signifikan karena penggunaan tepung bekatul dan tepung jagung yang sama sama memiliki kandungan protein yang tinggi. Berdasarkan Suarni (2009) menyatakan bahwa kenaikan kadar protein sejalan dengan prosentase tepung jagung yang ditambahkan, karena tepung jagung mengandung protein sebesar $11,02 \%$ [8]. Sedangkan menurut Damayanthi (2006) menyatakan bahwa kadar protein semakin meningkat secara nyata dengan semakin tingginya tingkat substitusi tepung bekatul, karena tepung bekatul mengandung protein sebesar 10,41\% [12]. Dengan demikian, proporsi tepung bekatul yang rendah dan tepung jagung yang tinggi hasilnya hampir sama dengan proporsi tepung bekatul yang tinggi dan tepung jagung yang rendah.

Pada produk food bar ini kandungan lemaknya berkisar 18,3 - 18,8\%. Perbedaan antara P1 sampai P5 tidaklah signifikan karena penggunaan tepung bekatul dan tepung jagung yang sama - sama memiliki kandungan lemak yang rendah. Dimana tepung jagung mengandung lemak sebesar $5,42 \%$ dan tepung bekatul mengandung lemak sebesar $2,13 \%$. Sehingga dengan proporsi tepung bekatul yang rendah dan tepung jagung yang tinggi hasilnya hampir sama dengan proporsi tepung bekatul yang tinggi dan tepung jagung yang rendah.

Kadar lemak tertinggi yaitu pada sampel P1. Sampel P1 merupakan Food Bar dengan proporsi $10 \%$ tepung bekatul dan $90 \%$ tepung jagung. Secara keseluruhan menurut syarat pangan darurat, semua perlakuan tidak memenuhi syarat tersebut. Yaitu kandungan lemak sebesar $35-45 \%$.

Kandungan lemak dalam pangan darurat mempunyai kontribusi penting yaitu sebagai salah satu penyumbang energi [13]. Lemak merupakan faktor penting yang harus diperhatikan dalam makanan karena dapat menyebabkan perubahan sifat pada makanan tersebut. Perubahannya bahkan dapat terjadi kearah yang tidak diinginkan seperti ketengikan. Lemak dapat menghambat proses gelatinisasi dengan cara sebagian lemak akan diserap oleh permukaan granula, sehingga terbentuk lapisan lemak yang bersifat hidrofobik disekeliling granula pati [2].

Pada produk food bar ini kandungan karbohidratnya berkisar $60,8-63,1 \%$. Perbedaan antara P1 sampai P5 tidaklah signifikan karena penggunaan tepung bekatul dan tepung jagung yang sama - sama memiliki kandungan karbohidrat yang tinggi. Tepung jagung mengandung karbohidrat sebesar $79,95 \%$ dan tepung bekatul mengandung karbohidrat sebesar $70,57 \%$. Sehingga dengan proporsi tepung bekatul yang rendah dan tepung jagung yang tinggi hasilnya hampir sama dengan proporsi tepung bekatul yang tinggi dan tepung jagung yang rendah. Kadar karbohidrat tertinggi yaitu pada sampel P2. Secara keseluruhan menurut syarat pangan darurat, semua perlakuan tidak memenuhi syarat tersebut, yaitu kandungan karbohidrat sebesar $40-50 \%$.

Pada pangan darurat kandungan karbohidrat sangatlah penting untuk memenuhi kecukupan kalori terbesar selain dari protein dan lemak. Menurut Brisske et al. (2004) menyatakan bahwa karbohidrat menyumbang 40-50\% kalori dengan nilai 4 kkal per gram [14].

Berdasarkan jumlah energi pada setiap food bar menggunakan metode Atwater, dimana metode ini merupakan metode tidak langsung dengan mengkonversi nilai energi berdasarkan kandungan protein, lemak dan karbohidrat tanpa mempertimbangkan nilai serat, dapat diketahui semua perlakuan tidak memenuhi syarat minimal pangan darurat yaitu $233 \mathrm{kkal}$. Akan tetapi, total energi yang paling mendekati syarat energi pangan darurat adalah P1 (tepung bekatul 10\%: tepung jagung 90\%).

Mutu organoleptik pada food bar berbahan baku tepung bekatul dan tepung jagung dapat dipengaruhi oleh berbagai hal. Rasa manis pada food bar diperoleh dari penambahan madu, selain itu dengan penambahan margarine juga dapat digunakan sebagai pembangkit rasa pada food bar [15]. Tingkat kesukaan panelis terhadap rasa food bar berbahan dasar tepung bekatul dan tepung jagung semakin menurun dengan bertambahnya tepung bekatul. Hal ini disebabkan karena semakin banyak bekatul maka rasa food bar menjadi pahit. 
Sarbini (2009) menyatakan bahwa rasa pahit disebabkan karena masih terdapat saponin didalam bekatul yang digunakan sebagai bahan baku [16]. Rasa pahit yang berlebihan diduga berhubungan dengan kerusakan protein.

Aroma berkaitan erat dengan indera penciuman, aroma yang dikatakan enak merupakan perpaduan dari komponen bahan - bahan yang sangat tepat [17]. Aroma pada food bar diperoleh dari beberapa bahan penyusunnya seperti tepung bekatul, tepung jagung dan kacang tanah. Tepung jagung dan kacang tanah digunakan untuk menutupi aroma tepung bekatul yang tidak begitu enak.

Dari food bar yang dihasilkan memiliki aroma bekatul dan sedikit langu sejalan dengan tingginya tepung bekatul yang digunakan maka aroma bekatul dalam food bar akan semakin tercium. Adanya aroma khas bekatul disebabkan oleh adanya tokoferol (komponen volatile) pada bekatul [15].

Tekstur food bar dapat dipengaruhi oleh bahan dasar, ketebalan cetakan dan suhu oven yang terlalu tinggi. Dengan penembahan madu juga akan mempengaruhi proses pengempukan. Penggunaan madu lebih diutamakan dibandingkan dengan penggunaan gula. Hal ini dikarenakan dengan menggunakan madu tekstur food bar yang dihasilkan lebih tidak mudah patah tetapi mudah digigit. Selain itu, dengan menggunakan madu dalam pembuatan food bar tidak diperlukan lagi telur sebagai bahan pengikat karena telah ada madu dan margarine yang dapat menyatukan bahan bahan lain.

Kandungan tepung jagung yang lebih dominan akan membuat tekstur food bar menjadi lebih keras. Menurut Azam (2000) dalam Ramadhani dkk. (2012) menyatakan bahwa semakin banyak tepung jagung yang digunakan maka tekstur produk akan semakin keras. Sehingga food bar yang dihasilkan tidak mudah retak akan tetapi mudah digigit [17].

Selain itu, food bar yang memiliki proporsi tepung bekatul lebih banyak cenderung memiliki tekstur yang lebih mudah hancur. Hal ini dikarenakan bekatul memiliki kandungan serat lebih tinggi [12]. Hal ini menyebabkan, food bar yang menggunakan proporsi bekatul lebih banyak membutuhkan adonan perekat lebih banyak.

Warna food bar yang dihasilkan berkisar dari warna kuning hingga kuning kecoklatan.Sedangkan warna food bar yang berbahan dasar tepung gandum pada perlakuan kontrol memiliki warna kecoklatan. Warna dihasilkan dari perpaduan warna tepung yang digunakan. Tepung jagung cenderung bewarna kuning. Sedangkan, warna pada tepung bekatul bervariasi coklat muda sampai coklat muda [12].

Menurut Winarno (1991) dalam Wiyono (2012) menyatakan bahwa bekatul memiliki kandungan gula reduksi yang relative tinggi, sehingga menyebabkan terjadinya reaksi Mailard. Semakin besar konsentrasi tepung bekatul maka warna food bar yang dihasilkan semakin coklat [18].

\section{KESIMPULAN}

Berdasarkan hasil analisis dan pembahasan dapat ditarik beberapa kesimpulan bahwa tidak ada perbedaan yang signifikan pada mutu gizi (protein, lemak, karbohidrat) food bar berbahan baku tepung bekatul dan tepung jagung serta food bar berbahan baku tepung gandum; Ada perbedaan yang signifikan pada mutu organoleptik (warna, rasa, aroma, tekstur) food bar berbahan baku tepung bekatul dan tepung jagung. Semakin tinggi penambahan tepung jagung maka mutu organoleptik semakin baik; Formulasi food bar berbahan baku tepung bekatul dan tepung jagung yang tepat sesuai syarat pangan darurat dan baik daya terimanya adalah food bar dengan proporsi tepung bekatul : tepung jagung (10:90). Dimana dalam 50 gram/batang mengandung energi 232,43 kkal, protein 6,35 gram, lemak 9,41 gram dan karbohidrat 30,58 gram serta memiliki tingkat kesukaan "suka" pada rasa, aroma dan tekstur, dan tingkat kesukaan "sangat suka" pada warna.

\section{DAFTAR RUJUKAN}

1. Badan Nasional Penanggulangan Bencana. 2013. Info Bencana, Edisi Maret 2013, hal. 1.

2. Luthfiyanti R, Ekafitri E, Desnilasari D. 2011. Pengaruh Perbandingan Tepung dan Pure Pisang Nangka pada Proses Pembuatan Food Bar Berbasis Pisang Sebagai Pangan Darurat. Prosiding SNaPP: Sains dan Teknologi. ISSN: 2089-3582. Vol.2, No.1; 239-246.

3. Zoumas LB, et al. 2002. High-Energy, NutrientDense Emergency Relief Food Product. Food and Nutrition Board. Institute of Medicine. National Academy Press. Washington DC: p.129-40.

4. Pratama TA, Rahman T, Rahman N. 2011. Analisis Kepuasan Konsumen Food Bar Kabupaten Subang. Prosiding SNaPP: Sains 
dan Teknologi. ISSN: 2089-3582. Vol. 2, No. 1; 311-318.

5. Setiawan I. 2011. Pengaruh Tingkat Pencapuran Tepung Ubi Jalar Merah dengan Bekatul Padi Terhadap Karakteristik Biskuit yang Dihasilkan. Skripsi. Program Studi Teknologi Hasil Pertanian Fakultas Teknologi Pertanian Universitas Andalas Padang. Hal: 38.

6. Aftasari F. 2003. Sifat Fitokimia dan Organoleptik Sponge Cake yang Ditambah Tepung Bekatul Rendah Lemak. Skripsi. Jurusan Gizi Masyarakat dan Sumber Daya Keluarga Fakultas Pertanian Institut Pertanian Bogor. Hal: 8-15.

7. Richana N, Budianto A, Mulyawati I. 2010. Pembuatan Tepung Jagung Termodifikasi dan Pemanfaatannya untuk Roti. ISBN : 978-9798940-29-3. Prosiding Pekan Serelia Nasional. 2010 : 446-454.

8. Suarni. 2009. Prospek Pemanfaatan Tepung Jagung untuk Kue Kering (Cookies). Balai Penelitian Tanaman Serelia. Hal: 386-409.

9. BPTP. 2008. Pembuatan Tepung Jagung. Jawa Tengah. Hal 2.

10. Ricelina UJ. 2007. Studi Pembuatan Makanan Padat (Food Bars) Berenergi Tinggi Menggunakan Tepung Komposit (Tepung Gaplek, Tepung Kedelai, Tepung Terigu) dan Penambahan Tepung Porang (Amorphophallus Onchophyllus) sebagai Bahan Pengikat. Tidak Dipublikasikan [Skripsi]. Malang: Universitas Brawijaya.

11. Persagi. 2009. Tabel Komposisi Pangan Indonesia. Jakarta: PT Elex Media Komputindo. Gramedia. Hal 2.
12. Damayanthi E dan Listyorini DI. 2006. Pemanfaatan Tepung Bekatul Rendah Lemak pada Pembuatan Keripik Simulasi. Jurnal Gizi dan Pangan. 2006; 1 (2) : 34-44.

13. Institute of Medicine (IOM). 2002. Dietary Reference Intake for Emergency Food Product: 10-13.

14. Brisske LK, Lee SY, Klein BP and Cadwallder KR. 2004. Development of a Prototype HighEnergy, Nutrient Dense Food Product for Emergency Relief. University of Illinois Urbana Champaigne. Food Rev. Int, 6: 225-264.

15. Wulandari M, Handasari E. 2010. Pengaruh Penambahan Bekatul Terhadap Kadar Protein dan Sifat Organoleptik Biskuit. Program DIII Gizi Fakultas Ilmu Keperawatan dan Kesehatan Universitas Muhammadiyah Semarang. Tugas Akhir. Hal : 9-10.

16. Sarbini D, Rahmawati S, Kurnia P. Uji Fisik, Organoleptik, dan Kandungan Zat Gizi Biskuit Tempe-Bekatul dengan Fortifikasi Fe dan Zink untuk Anak Kurang Gizi. Jurnal Penelitian Sains dan Teknologi. 2009; Hal 10.

17. Ramadhani AG, dkk. 2012. Analisis Proximat, Antioksidan dan Kesukaan Sereal Makanan dari Bahan Dasar Tepung Jagung ( Zea mays L.) dan Tepung Labu Kuning (Cucurbita moschata Durch). Buletin Anatomi dan Fisiologi. 2012; XX Nomor 2. Hal: 12.

18. Wiyono FP. 2012. Evaluasi Mutu Gizi dan Organoleptik "Butter Cookies" MOCORIN (Modifikasi Tepung Jagung Lokal (Zea mays L.) - Bekatul). Skripsi. Universitas Kristen Satya Wacana. 